\title{
Autocastration and Autoamputation of the Penis in a Patient with Delusions of Sexual Guilt
}

\author{
Craig B. Franke M.D. (PGY4) \\ Scott \& White - Texas A\&M University Health Science Center, cbfranke@swmail.sw.org \\ James A. Rush M.D. (PGY3) \\ Scott \& White - Texas A\&M University Health Science Center, jxrush@swmail.sw.org
}

Follow this and additional works at: https://jdc.jefferson.edu/jeffjpsychiatry

Part of the Psychiatry Commons

Let us know how access to this document benefits you

\section{Recommended Citation}

Franke, Craig B. M.D. (PGY4) and Rush, James A. M.D. (PGY3) (2007) "Autocastration and Autoamputation of the Penis in a Patient with Delusions of Sexual Guilt," Jefferson Journal of Psychiatry. Vol. 21 : Iss. 1 , Article 2.

DOI: https://doi.org/10.29046/JJP.021.1.002

Available at: https://jdc.jefferson.edu/jeffjpsychiatry/vol21/iss1/2

This Article is brought to you for free and open access by the Jefferson Digital Commons. The Jefferson Digital Commons is a service of Thomas Jefferson University's Center for Teaching and Learning (CTL). The Commons is a showcase for Jefferson books and journals, peer-reviewed scholarly publications, unique historical collections from the University archives, and teaching tools. The Jefferson Digital Commons allows researchers and interested readers anywhere in the world to learn about and keep up to date with Jefferson scholarship. This article has been accepted for inclusion in Jefferson Journal of Psychiatry by an authorized administrator of the Jefferson Digital Commons. For more information, please contact: JeffersonDigitalCommons@jefferson.edu. 


\title{
Autocastration and Autoamputation of the Penis in a Patient with Delusions of Sexual Guilt
}

Craig B. Franke, M.D. (PGY4) and James A. Rush, M.D. (PGY3)

\begin{abstract}
Genital self-mutilation (GSM) is a rare event that is commonly associated with psychotic disorders; we report an occurrence in the context of psychosis and drug use. We also review the etiologies of this phenomenon and how these etiologies differ across gender.
\end{abstract}

\section{CASE PRESENTATION}

A 20-year-old man presented to the emergency trauma service status-post autocastration and self-inflicted amputation of his penis. He had reportedly used a utility knife to sever his scrotum, testicles and penis without anesthesia some hours prior. His adopted parents consented to reimplantation and the patient also underwent exploratory surgery for anemia. Ultimately, the replanted tissue was not viable and was removed; a temporary suprapubic catheter was placed. He was eventually transferred to the inpatient psychiatric unit for further management.

On initial psychiatric evaluation, he explained that he had died and was without feeling; in order to "wake up," he severed his genitals. He further declared that he had previously committed the sin of "lust" and that his penis was the source, requiring removal as the path to atonement in God's eyes. During the 70 hours prior to admission, he had been unable to sleep and had not eaten or drank. He reported a history of substance use consisting of alcohol, opium tea, mushrooms, cocaine, and marijuana. Although he stated his most recently used substance was marijuana five days prior to admission, his urine drug screen was positive only for barbiturates. All other labs and studies were essentially normal.

On initial evaluation, he was lucid, oriented, and spoke with appropriate rate, rhythm, and spontaneity. He did not exhibit any abnormal mannerisms or gestures. His mood was "fine" but his affect was flat and he appeared apathetic. He expressed relief about the loss of his genitalia. He denied any 
racing thoughts, grandiosity, depression, hallucinations (auditory or visual), and suicidal or homicidal ideations. Furthermore, he did not present with ideas of reference, thought blocking, loosening of associations, or grossly catatonic or disorganized speech or behavior. He was started on risperidone 2 milligrams twice daily which he tolerated without side effects.

The patient had never before required psychiatric hospitalization or psychotropic medication. He had no history of suicide or homicide attempts.

The patient's family history was unknown as he was adopted at 3 weeks. No prior medical history, allergies, or current medications were documented. He was described by his adoptive parents as having a "normal" childhood without any incidence of abuse or neglect. Furthermore, he was social with friends and family and did not display strange behavior or apathy as a child or teenager. He graduated high school and attended a university for one year. However, he subsequently transferred to a two-year college due to poor academic performance; at the two-year program, he exhibited depressive symptoms with progressively hyper-religious delusions. He ultimately discontinued college and moved back into his parents' home.

In later follow-up, the patient expressed a long-held desire to have his male genitalia removed secondary to a belief that he was more female than male. However, he considered himself as heterosexual in orientation.

At psychiatric follow-up after discharge, the patient was without suicidal ideations and no longer expressed delusions of sexual guilt. However, he did not express regret about removing his gentials.

\section{DISCUSSION}

The current case of autocastration by a man suffering from psychotic sexual guilt supports earlier findings in men (see below) that most cases involve psychosis. In addition, the patient's history of drug use (especially marijuana and cocaine) may indicate that he became psychotic only or partly because of drug use and that he does not have a primary psychotic disorder.

Reported cases of GSM are rare. As of 2006, Stunnel et al. found that there were only 122 cases reported; they and others also conclude that most cases occur during psychosis $(2,4,6)$. Waugh further suggests that GSM most commonly occurs in men with chronic paranoid schizophrenia and a history of delusions that only castration will absolve them of guilt for sexual wrongdoing (7). However, Marckmann et al. note that in women, GSM occurs more frequently in the context of personality disorders than of

Jefferson Journal of Psychiatry, Volume 21, Number 1

(C) 2007 by the authors

ISSN 1935-0783

On the Web: jdc.jefferson.edu/jeffjpsychiatry 
psychosis (3). In non-psychotic individuals, GSM results from intoxication, attempts of transsexuals at sex change operations, attempted abortions, and character disorders $(2-4,6)$.

Duggal et al. offer an interesting inversion of the commonly accepted relationship between psychosis and autocastration: they speculate that psychosis can be an effect rather than a cause of the phenomenon and that the loss of testosterone leads to psychosis (1). However, even if valid in some cases, their notion does not explain the majority of cases of autocastration in psychotic patients in which psychosis preceeds the act.

How can clinicians identify patients at risk for GSM? Psychosis with delusions of sexual guilt is an obvious red flag given the epidemiology of GSM. Shweitzer further suggests that psychotic patients with sexual conflict, prior self-destructive behavior, depression, severe childhood deprivation, and premorbid personality disorders are at risk (5). Due to the fortunate infrequency of the event, however, more precise identification of individuals at risk remains difficult.

\section{SOURCE INFORMATION}

From the Department of Psychiatry, Scott \& White Texas A\&M University Health Science Center, Temple, Texas. Direct inquiries to: cbfranke@swmail.sw.org.

\section{REFERENCES}

1. Duggal HS, Jagadheesan K, and Nizamie SH. Acute onset of schizophrenia following autocastration. Can J Psychiatry 2002; 47: 283-284

2. Greilsheimer H and Groves JC. Male genital self-mutilation. Arch Gen Psychiatry $1979 ; 36: 441-446$

3. Marckmann S, Garlipp P, Krampf K, and Haltenhof H. Genital self-mutilation and Erotomania. Ger J Psychiatry 2005; 8:38-41

4. Romilly CS and Isaac MT. Male genital self-mutilation. Br J Hosp Med 1996; 55(7): 427-31

5. Schweitzer I. Genital Self-amputation and the Klingsor Syndrome. Aust N Z Psychiatry 1990; 24(4): 566-9

6. Stunnell H, Power RE, Floyd M, and Quinlan DM. Genital self-mutilation. Int J Urol 2006; 13(10): 1358-60

Jefferson Journal of Psychiatry, Volume 21, Number 1

ISSN 1935-0783

(C) 2007 by the authors

On the Web: jdc.jefferson.edu/jeffjpsychiatry 
7. Waugh AC. Autocastration and biblical delusions in schizophrenia. Br J Psychiatry 1986; 149: 656-659

Jefferson Journal of Psychiatry, Volume 21, Number 1 